\title{
Caddisflies (Trichoptera) of the Świętokrzyski National Park
}

\author{
Krzysztof GÓRECKI \\ University of Life Sciences, Department of Entomology and Environmental Protection, Dabrowskiego 159, \\ 60-594 Poznań, Poland; e-mail: goral@up.poznan.pl
}

\begin{abstract}
This faunistic study was carried out in the period 2008-2014 in the Natura 2000 Lysogóry (PLH260002) area, which is situated entirely in the Świętokrzyski National Park (ŚPN). The study revealed the occurrence of 82 caddisfly species (Trichoptera). The insects were caught by light-trapping at 10 sites in the National Park and at one locality on its boundary. Five caddisfly species from the Polish Red List were found. Stenophylax vibex (Curtis, 1834), a rare species in Poland, has so far been found only in the ŚPN. Fifty-three species of caddisflies were found for the first time in the Świętokrzyski National Park, 19 of which are new to the Świętokrzyskie Mountains area. The study did not confirm the presence of sixteen species recorded previously but it has raised the total number of caddisfly species recorded in the Świetokrzyski National Park to 98.
\end{abstract}

Key words: Natura 2000, Łysogóry, Polish national park, light-trap

\section{INTRODUCTION}

The state of knowledge of the caddisfly fauna, and indeed of most insects, in the Świętokrzyski National Park (ŚPN) is unsatisfactory. The caddisflies in the Świętokrzyskie Mountains (ŚM) as a whole and in the ŚPN in particular were researched in 1919 (Pongrácz 1919), 1922 (Prüffer 1922), 1960 - 1962, 1980 - 1985 (Riedel \& Majecki 1989), 1984 and 1986-1988 (Szczęsny 1990). Pongrácz and Prüffer jointly found a total of 18 species in the ŚM. Later work failed to confirm the presence of Rhyacophila vulgaris Pictet, 1834, Setodes punctatus (Fabricius, 1793) and Anabolia nervosa (Curtis, 1834), recorded by Pongrácz (1919), and Semblis phalaenoides (Linnaeus, 1767), found by Prüffer (1922). The lastmentioned species is tending to recede from Poland in a north-easterly direction: nowadays S. phalaenoides is only found in the Biebrza National Park (Czachorowski \& Frąckiel 2003) and to the east of the city of Białystok (Górecki \& Buszko 2014). 41 species of caddisflies were found in the River Lubrzanka, to the north-west of the ŚPN (Majecki 1982, Bis et al. 1992). Riedel \& Majecki (1989) reported 90 caddisfly species from the ŚM but only 24 from the ŚPN. Szczęsny (1990) found another 24 in the streams of the ŚPN, whereby he regarded the identification of one species - Athripsodes commutauts (Rostock, 1873) - as uncertain. Up to that time, a total of 48 caddisfly species had been recorded in the ŚPN. The state of knowledge of Trichoptera in other national parks in Poland is incomplete. Only in 10 out of the 23 national parks in Poland has the caddisfly fauna been fairly well investigated (Babia Góra National Park, Białowieża NP, Biebrza NP, Bieszczady NP, Gorce NP, Pieniny NP, Polesie NP, Roztocze NP, Tatra NP and Wigry NP). No such research has been conducted so far in the Wolin NP, Wielkopolska NP or Warta Mouth NP (Riedel \& Majecki 1994, Czachorowski \& Majewski 2003, Banaszak et al. 2004, Buczyńska 2006, Buczyńska et al. 2007, Buczyńska 2008). The number of species in the parks varies from 12 in the Słowiński National Park to 79 in the Biebrza National Park.

Hydrographically, the ŚPN lies in the Vistula basin, in the catchment areas of the Nida and Kamienna. In the ŚPN, the watershed between the catchment areas of these two rivers runs 
mainly along the Łysogórskie and then the Klonowskie Ranges. Within the boundaries of the Park, the upper sections of the Rivers Lubrzanka and Bielanka drain into the Nida, while the Rivers Czarna Woda, Psarka, Pokrzywianka and Słupianka are tributaries of the Kamienna. The river network is rather irregular and is intimately associated with the geological structure of the underlying rocks. The northern slopes of the Łysogórskie Range are much richer in watercourses, of which there are 45, whereas only 11 streams flow down the southern slopes. This considerable difference between the density of watercourses is due primarily to the greater amount of precipitation on the northern side, its greater water retention capacity and the steeper slopes - average 50\% (max. 300\%o) (Ciupa et al. 2012). The density of flowing waters on the Klonowskie Range is much smaller, particularly on its northern side. The main sources are on the Łysogórskie Range: some 55 have been recorded there, but only around 10 elsewhere. The northern slopes of the Łysogórskie Range are more abundant in sources: those in the highest zone (500 - $400 \mathrm{~m}$ AMSL) are associated with Cambrian formations. The next zone $(360-320$ $\mathrm{m}$ AMSL) covers rock debris sources, which are largely dependent on precipitation. The few sources on the southern side of the Łysogórskie Range, carrying little water, are associated with Middle and Upper Cambrian formations. Around the Bukowa and Chełmowa Góra hills, the sources are springs associated with Devonian formations (Kupczyk et al. 2000). There are not many wetland areas in the Park - most of them lie in the source section of the Czarna Woda and on the southern slope of Bukowa Góra (Ciupa \& Sołtysik 2002). Except for the artificial pond on the Polanie Bilenik, there are no standing waters in the ŚPN.

The surface waters in the ŚPN, especially in the source sections, are of the highest quality class (Biernat et al. 2009). This is mainly because there are few sources of pollution. The waters in the upper sections of the streams in the Lysogórskie Range have a low $\mathrm{pH}$. Invertebrates tend to avoid waters with an excessively low $\mathrm{pH}$. Caddisflies are fairly resistant to acidic waters, although Szczęsny (1990) found that the number of their species falls dramatically when the water $\mathrm{pH}$ drops below 5. One of the reasons for the acidification of waters in the ŚPN is the emission of sulphur dioxide into the atmosphere. Fortunately, levels of this gas in the air are falling with every passing year (Degórski 2007).

The region's microclimate, its geological structure, hydrological network and unique plant communities, as well as phenomena specific to mountain areas like thermal inversions, suggest the possible occurrence of characteristic and unique species of caddisfly.

\section{STUdy AREA, MATERIAL AND METHODS}

The study was carried out in 2008-2014. The catches were performed every three or four days from April to November. The insects were caught using actinic light traps deployed at ten sites within the ŚPN and at one in the Park's buffer zone (Fig. 1). The trapping localities were situated in various parts of the ŚM, at different altitudes and in different habitat types. These localities were as follows:

1. Chelmowa Góra (UTM: EB03, $300 \mathrm{~m}$ AMSL) - the protective zone in the south-eastern part of the Park in the Pokrzywiański Range. In the immediate vicinity of the forester's lodge, where the light trap was hung up, there are two rivers, the Stupianka and the Pokrzywianka.

2. Dąbrowa protective zone (UTM: DB94, $280 \mathrm{~m}$ AMSL) - the ecotone between a woodland and meadow in the western part of the Dębniański and Czarna Woda valley. This area is situated on the northern side of the Łysogóra Range.

3. Close to the village of Święta Katarzyna by the forester's lodge, in the protective zone of the same name (UTM: DB94). This zone is situated at the foot of the highest elevation in the SM - the Łysica (612 m AMSL), on the western side of the Łysogóra Range. The altitude of the locality itself was $360 \mathrm{~m}$ AMSL. 


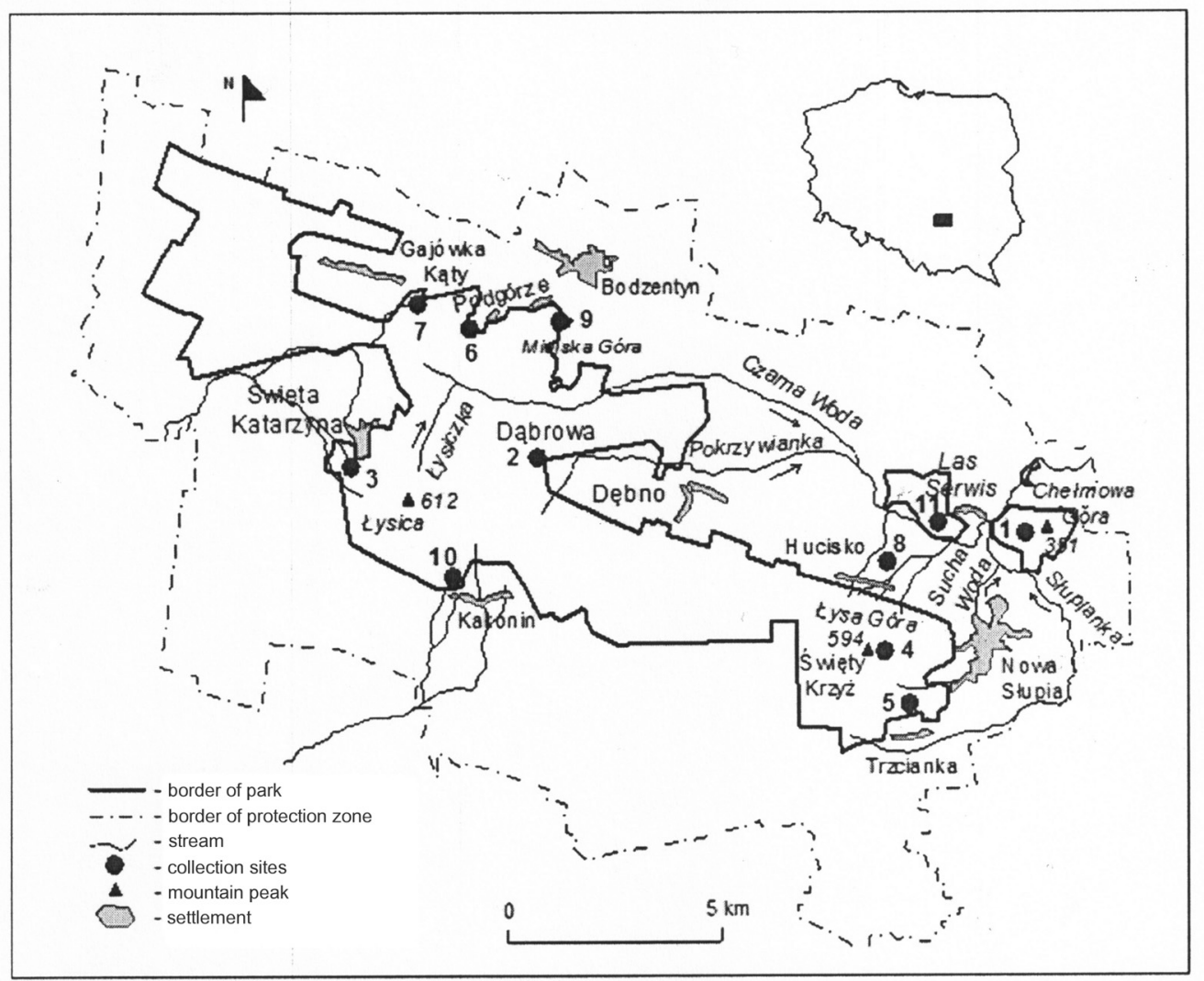

Fig. 1. Location of the collection sites in the Świętokrzyski National Park.

4. Święty Krzyż (UTM: EB03) - at the foot of the Łysa Góra (594.3 m AMSL), in the eastern part of the Łysogóra Range. The light trap was deployed near the ŚPN building. The altitude of ca $550 \mathrm{~m}$ AMSL was the highest elevation of all the trapping sites.

5. A forest hamlet in the ŚPN near the village of Trzcianka (UTM: EB03). The locality was on the south-eastern slopes of the Łysogóra Range at an altitude of $370 \mathrm{~m}$ AMSL.

6. Podgórze, by the forester's lodge near the confluence of the Czarna Woda stream (UTM: DB94). This locality was in the eastern part of the Klonowski Range in the "Podgórze" protective zone (altitude $340 \mathrm{~m}$ AMSL).

7. The land around the forester's lodge near the village of Psary-Kąty (Gajówka Kąty) (UTM: DB94), at an altitude of $320 \mathrm{~m}$ AMSL. This locality was in the central part of the Klonowski Range, at the western foot of the Psarska mountain (415 m AMSL).

8. The land around the forester's lodge near the village of Hucisko (UTM: EB03). This is the only locality not lying within the ŚPN but on its boundary (altitude ca $270 \mathrm{~m}$ AMSL).

9. The Miejska Góra locality lies at the foot of the mountain of the same name $(424 \mathrm{~m}$ AMSL) in the eastern part of the Klonowski Range (UMT: DB94) (altitude 390 m AMSL).

10. The land around the forester's lodge near the village of Kakonin (UMT: DB93) (altitude $400 \mathrm{~m}$ AMSL). The trapping site itself was on the southern side of the Łysogóra Range at the foot of the Agata (608 m AMSL) and Łysica (612 m AMSL) mountains. 
11. This locality, referred to as Las Serwis, was on SPN land near the village of Serwis (UMT: EB03). This, like the Chełmowa Góra protective zone, is a small enclave of the ŚPN, in the north-eastern part of the national park. The southern boundary of the enclave is the River Pokrzywianka. The trapping site lay at an altitude of $260 \mathrm{~m}$ AMSL.

The species diversity was estimated by Shannon index and Pielou's evenness index (Magurran 2004). To compare the similarity of the species composition at the several trapping localities, a Bray-Curtis dendrogram was drawn using the Ward' method in the $\mathrm{R}$ software package (R Core Team 2013). The statistical analysis covered only the number of individuals identified to species level.

To analyse dominance we used the following classes: eudominant (numbers $>10 \%$ ), dominant $(5.01-10 \%)$, subdominant $(2.01-5 \%)$ and recedent $(<2 \%)$ (Biesiadka \& Kowalik 1980).

In addition, the entire caddisfly fauna of the ŚM was compared with that from other parts of Poland using Jaccard's formula.

\section{RESULTS AND DisCUSSION}

\section{Species composition}

A total of 7161 caddisflies (82 species from 11 families) were caught (Table 1). The most numerous family was Limnephilidae (5759 individuals) with 39 species. The results of this study have increased the number of caddisfly species known from the ŚPN by 53. We found 19 species new to the ŚM. The following overview of these species is limited to rare species and to those from the Red List species (Szczęsny 2002).

\section{Ecnomus tenellus (Rambur, 1842)}

This limnobiont occurs principally in lakes and large rivers, but has also been recorded in peat bog pools. Seven females were caught at Chełmowa Góra from late June through July to early August 2008. Elsewhere in Poland it has been recorded mainly in lowland regions (Czachorowski 1998a, Czachorowski et al. 2002, Żurawlew et al. 2015).

\section{Hydropsyche siltalai Doehler, 1963}

The species is regarded as a potamobiont, more numerous in the cool rivers of the Polish lake districts. In the SPN caught from June to July, rarely in August, at the following localities:

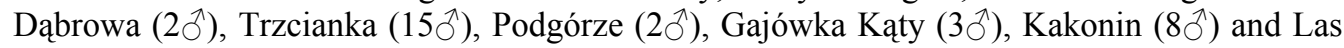
Serwis $\left(1{ }^{\Uparrow}\right)$. This species was first recorded for Poland by Szczęsny (1986) from the Western Beskid Mountains.

\section{Hydatophylax infumatus (McLachlan, 1865)}

This is a species living in flowing waters rich in detritus. In the ŚPN caught at the Dąbrowa in early August $2008(2 \hat{\jmath})$. Quite rare in Poland, but has been recorded in the ŚM region in and around the River Lubrzanka (Majecki 1982, Riedel \& Majecki 1989, Bis et al. 1992), the Masurian Lakeland (Szczepańska 1958) and the Roztocze Upland (Serafin 2004). H. infumatus is a Red List species (Least Concern - LC) (Szczęsny 2002).

\section{Ironoquia dubia (Stephens, 1837)}

A rheophilic limnoxen. Trapped from September to October at Chełmowa Góra (69),

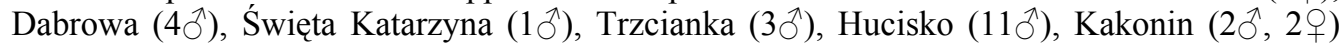
and Las Serwis $(2 \hat{\jmath})$. Not recorded in other mountain areas in Poland, but has been found in 
regions adjoining the ŚM - the Lublin Upland and the Sandomierz Basin (Czachorowski 1994, Czachorowski et al. 2000).

\section{Rhadicoleptus alpestris (Kolenati, 1848)}

A tyrphophilic limnoxen. Caught at Dąbrowa in May and June 2008 (18 , 2 9 ) and 2012

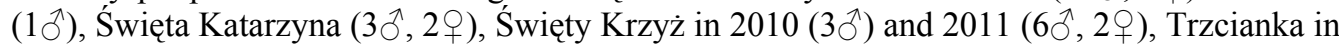

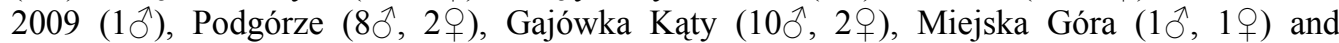
Kakonin $\left(3{ }^{\Uparrow}\right)$. Elsewhere in the Polish mountains, caught in the Western Beskids (Tomaszewski 1965) and Tatras (Riedel 1962, Szczęsny 1986). Larvae were caught in Białowieża National Park (Czachorowski 1998b). A Red List species (Near Threatened - NT) (Szczęsny 2002).

\section{Stenophylax vibex (Curtis, 1834)}

The species is recently confirmed as new to Poland (Górecki \& Czachorowski 2010). In the ŚPN single specimens were caught at almost all the localities except Podgórze and Las Serwis in late May and June. Large swarms were observed in September and October, and some specimens were caught as late as November. The largest number of individuals was trapped at Dąbrowa $\left(133{ }^{\lambda}, 10\right.$ ) $)$ in 2008. A total of 456 specimens were caught. To this day S. vibex has not been recorded anywhere else beyond the boundaries of the SPN. It frequently comes to light, but all the very many attempts to attract it to light traps in other parts of Poland have failed. In Germany the species is endangered and is listed in that country's Red Data Book (Klima 1998). In one of the German Länder - Sachsen-Anhalt - it is found only in the Harz Mountains, in streams with stony or gravelly beds (Hohmann et al. 2004).

\section{Athripsodes bilineatus (Linnaeus, 1758)}

The species is regarded as a limnoxen. In the ŚPN caught at the Las Serwis locality in early July $2014\left(1{ }^{\Im}\right)$. Recorded in the ŚM by Pongrácz (1919) but not in later field studies (Riedel \& Majecki 1989, Szczęsny 1990). Quite rare in Poland, but has been recorded in the Western Sudetens and the Pieniny Mountains (Tomaszewski 1965, Szczęsny 1965, Riedel 1978).

\section{Ceraclea alboguttata (Hagen, 1860)}

A limnoxen. In the ŚPN caught at the Meska Góra in June (1ㅇ) and July 2013 (1ठ̂). Recorded in the ŚM by Riedel \& Majecki 1989 in the Cedzynia dam reservoir. A Red List species (Data Deficient - DD) (Szczęsny 2002).

\section{Oecetis notata (Rambur, 1842)}

It is regarded as a limnophil. In the ŚPN trapped at Chełmowa Góra in late June $2008\left(1{ }^{\lambda}\right.$, 1ㅇ). Szczęsny (2002) considered this species to be extinct (Ex?), but subsequent fieldwork revealed its presence in the Brudzeń Landscape Park (Abraszewska-Kowalczyk et al., 2002) and in the River Biebrza (Czachorowski \& Graf, 2006).

\section{Ylodes simulans (Tieder, 1929)}

A limnoxen. Caught at Chełmowa Góra in late July $2008\left(1{ }^{\top}\right)$. Fairly rare in both Poland and elsewhere in Europe, it has a northern and central-European distribution. Imagines were recently caught in Poland in the River Nysa Lużycka (Lubuskie province) (Rychła \& Buczyńska 2013) and in the River Wrześnica in the province of Wielkopolska (Górecki, unpublished data). A Red List species (Least Concern - LC) (Szczęsny 2002). 
Table 1. Caddisflies recorded in the period 2008-2014 in the area of the Świętokrzyski National Park; N - total number of collected individuals, D - index of dominance [\%], * - the species new to the SPN, ! - the species new to the ŚM region, \#-Red List species. The numbering of study sites like in the Fig. 1.

\begin{tabular}{|c|c|c|c|c|}
\hline No. & Species & Study sites & $\mathrm{D}$ & $\mathrm{N}$ \\
\hline 1. & Rhyacophila fasciata Hagen, 1859 & 10,11 & 0,03 & 2 \\
\hline \multirow[t]{2}{*}{2.} & Rhyacophila nubila (Zetterstedt, 1840) * & 2,7 & 0,04 & 3 \\
\hline & Hydroptila sp. (females) & 7 & 0,04 & 3 \\
\hline 3. & Hydroptila forcipata Eaton, $1873 *$ ! & 4 & 0,01 & 1 \\
\hline 4. & Agraylea sexmaculata Curtis, 1834 & 11 & 0,01 & 1 \\
\hline \multirow{2}{*}{5.} & Ecnomus tenellus (Rambur, 1842) *! & 1 & 0,10 & 7 \\
\hline & Polycentropididae sp. (females) & 6,9 & 0,04 & 3 \\
\hline 6. & Cyrnus trimaculatus (Curtis, 1834) * & 1 & 0,01 & 1 \\
\hline 7. & Holocentropus dubius (Rambur, 1842) *! & 4,7 & 0,08 & 6 \\
\hline 8. & Neureclipsis bimaculata (Linnaeus, 1761) * & 1 & 0,03 & 2 \\
\hline 9. & Polycentropus flavomaculatus (Pictet, 1834) & 1 & 0,01 & 1 \\
\hline 10. & Plectrocnemia conspersa (Curtis, 1834) & $1,2,3,4,5,6,7,10,11$ & 0,40 & 29 \\
\hline & Polycentropus irroratus (Curtis, 1835)* & 6 & 0,01 & 1 \\
\hline & Psychomyia pusilla (Fabricius, 1781)* & 1 & 0,01 & 1 \\
\hline & Hydropsyche sp. (females) & $1,2,3,4,5,6,7,8,9,10,11$ & 9,47 & 678 \\
\hline & Hydropsyche angustipennis (Curtis, 1834) * & 11 & 0,01 & 1 \\
\hline & Hydropsyche bulbifera McLachlan, $1878 *$ & $1,2,8,11$ & 0,24 & 17 \\
\hline & Hydropsyche contubernalis McLachlan, $1865 *$ & $1,2,4,5,6,7,8,9,11$ & 1,28 & 92 \\
\hline & Hydropsyche fulvipes (Curtis, 1834) *! & $5,8,9,10$ & 0,15 & 11 \\
\hline & Hydropsyche instabilis (Cutris, 1834) * & $1,2,3,4,5,7,9,10,11$ & 1,30 & 93 \\
\hline & Hydropsyche pellucidula (Curtis, 1834) & $1,3,4,6,7,8,9,11$ & 0,64 & 46 \\
\hline & Hydropsyche siltalai Doehler, $1963 *$ ! & $2,5,6,7,10,11$ & 0,43 & 31 \\
\hline & Hydropsyche saxonica McLachlan, 1884 & 1 & 0,04 & 3 \\
\hline & Agrypnia varia (Fabricius, 1793$) *$ & 4 & 0,04 & 3 \\
\hline & Oligotricha striata (Linnaeus, 1758) & $4,6,7$ & 0,11 & 8 \\
\hline & Phryganea bipunctata Retzius, $1783 *$ ! & 6 & 0,01 & 1 \\
\hline 24. & Phryganea grandis Linnaeus, $1761 *$ & $1,2,5,6,7,8$ & 0,57 & 41 \\
\hline & Trichostegia minor (Curtis, 1834) & 2 & 1,10 & 79 \\
\hline & Goera pilosa (Fabricius, 1775) & $1,4,6,7,11$ & 1,19 & 85 \\
\hline & Silo nigricornis (Pictet, 1834) * ! & 1,2 & 0,43 & 31 \\
\hline & Silo pallipes (Fabricius, 1781) & 1,11 & 0,11 & 8 \\
\hline & Lepidostoma basale (Kolenati, 1848) * & 1,11 & 0,14 & 10 \\
\hline & Lepidostoma hirtum (Fabricius, 1781) *! & 4 & 0,01 & 1 \\
\hline & Anabolia furcata Brauer, 1857 * & $1,2,5,7,8,10,11$ & 0,29 & 22 \\
\hline & Chaetopteryx villosa (Fabricius, 1798) & $1,2,4,5,7$ & 0,14 & 10 \\
\hline & Glyphotaelius pellucidus (Retzius, 1783) * & $1,2,4,5,6,7,8,11$ & 1,45 & 104 \\
\hline & Grammotaulius nigropunctatus (Retzius, 1783) * & $1,2,4,6,7$ & 0,96 & 69 \\
\hline & Halesus digitatus (Schrank, 1781) & $1,2,3,4,5,7,8,9,10,11$ & 3,80 & 272 \\
\hline & Halesus radiatus (Curtis, 1834) *! & 1,2 & 0,74 & 53 \\
\hline & Halesus tesselatus (Rambur, 1842)* & $1,2,3,5,7,8,9,10,11$ & 3,03 & 217 \\
\hline & Hydatophylax infumatus (McLachlan, 1865) * \# & 2 & 0,03 & 2 \\
\hline 39. & Ironoquia dubia (Stephens, 1837) *! & $1,2,3,5,8,10,11$ & 0,43 & 31 \\
\hline & Limnephilus affinis Curtis, $1834 *$ & $2,4,6$ & 0,08 & 6 \\
\hline & Limnephilus auricula Curtis, 1834 & $1,2,3,4,5,6,7,8,9,10,11$ & 5,70 & 408 \\
\hline & Limnephilus bipunctatus Curtis, $1834 *$ ! & $1,2,3,4,7,9,11$ & 0,47 & 34 \\
\hline & Limnephilus binotatus Curtis, 1834 & 4,8 & 0,21 & 15 \\
\hline & Limnephilus coenosus Curtis, 1834 & 4 & 0,04 & 3 \\
\hline & Limnephilus decipiens (Kolenati, 1848) * & $2,4,5,6,7,10$ & 0,78 & 56 \\
\hline & Limnephilus extricatus McLachlan, 1865 * & $1,3,4,7,11$ & 0,22 & 16 \\
\hline 47. & Limnephilus flavicornis (Fabricius, 1787) & $1,2,4,5,6,7,10$ & 2,11 & 151 \\
\hline 48. & Limnephilus fuscicornis Rambur, $1842 *$ & $1,4,8$ & 0,04 & 3 \\
\hline 49. & Limnephilus griseus (Linnaeus, 1758) & $1,2,3,4,5,6,7,8,9,10,11$ & 11,19 & 801 \\
\hline 50. & Limnephilus hirsutus (Pictet, 1834) * & $1,2,5$ & 0,07 & 5 \\
\hline
\end{tabular}

Continued on the next page 


\begin{tabular}{|c|c|c|c|c|}
\hline No. & Species & Study sites & $\mathrm{D}$ & $\mathrm{N}$ \\
\hline 51. & Limnephilus ignavus McLachlan, $1865 *$ & $1,2,3,4,5,6,7,8,9,10,11$ & 3,97 & 284 \\
\hline 52. & Limnephilus lunatus Curtis, 1834 & $1,2,3,4,5,6,7,8,9,10,11$ & 4,66 & 334 \\
\hline 53. & Limnephilus marmoratus Curtis, 1834 *! & $4,7,10$ & 0,04 & 3 \\
\hline 54. & Limnephilus nigriceps (Zetterstedt, 1840) * & $4,7,0$ & 0,01 & 1 \\
\hline 55. & Limnephilus politus McLachlan, 1865 * & 4 & 0,01 & 1 \\
\hline 56. & Limnephilus rhombicus (Linnaeus, 1758) * & $1,2,3,4,6,7,8,9,10,11$ & 3,07 & 220 \\
\hline 57. & Limnephilus sparsus Curtis, 1834 & $1,2,3,4,5,6,7,8,9,10,11$ & 19,76 & 1415 \\
\hline 58. & Limnephilus stigma Curtis, $1834 *$ & $1,2,4,6,7$ & 0,60 & 43 \\
\hline 59. & Limnephilus subcentralis Brauer, 1857 * & 1,4 & 0,10 & 7 \\
\hline 60. & Limnephilus vittatus (Fabricius, 1798) & 4,6 & 0,11 & 8 \\
\hline 61. & Micropterna lateralis (Stephens, 1837) & 8,10 & 0,03 & 2 \\
\hline 62. & Potamophylax cingulatus (Stephens, 1837) & $2,5,10$ & 0,54 & 39 \\
\hline 63. & Potamophylax latipennis (Curtis, 1834) & 5 & 0,01 & 1 \\
\hline 64. & Potamophylax luctuosus (Piller, 1783) & 2 & 0,03 & 2 \\
\hline 65. & Potamophylax nigricornis (Pictet, 1834) & 5 & 0,01 & 1 \\
\hline 66. & Potamophylax rotundipennis (Brauer, 1857) & $1,2,8,11$ & 0,59 & 42 \\
\hline 67. & Rhadicoleptus alpestris (Kolenati, 1848) *! \# & $2,3,4,5,6,7,9,10$ & 0,91 & 65 \\
\hline 68. & Stenophylax permistus McLachlan, 1895 & $1,2,3,4,5,6,7,8,9,10,11$ & 8,92 & 639 \\
\hline 69. & Stenophylax vibex Curtis, $1834 * !$ & $1,2,3,4,5,7,8,9,10$ & 6,37 & 456 \\
\hline 70. & Sericostoma personatum (Spence, 1826) & 3 & 0,01 & 1 \\
\hline 71. & Odontocerum albicorne (Scopoli, 1763) & 2 & 0,01 & 1 \\
\hline & Athripsodes bilineatus (Linnaeus, 1758) * & 11 & 0,01 & 1 \\
\hline 73. & Athripsodes cinereus (Curtis, 1834) * & 11 & 0,01 & 1 \\
\hline 74. & Ceraclea alboguttata (Hagen, 1860) * \# & 9 & 0,03 & 2 \\
\hline 75. & Ceraclea dissimilis (Stephens, 1836)* & 9,11 & 0,06 & 4 \\
\hline 76. & Ceraclea fulva (Rambur, 1842) *! & 11 & 0,01 & 1 \\
\hline & Mystacides longicornis (Linnaeus, 1758) * & $1,9,11$ & 0,10 & 7 \\
\hline 78. & Oecetis furva (Rambur, 1842)*! & 9 & 0,01 & 1 \\
\hline 79. & Oecetis lacustris (Pictet, 1834) *! & $1,9,11$ & 0,08 & 6 \\
\hline 80. & Oecetis notata (Rambur, 1842$) *$ ! \# & 1 & 0,01 & 1 \\
\hline & Oecetis ochracea (Curtis, 1825)* & 1,11 & 0,06 & 4 \\
\hline \multirow{2}{*}{\multicolumn{2}{|c|}{ 82. Ylodes simulans (Tieder, 1929) *!\# }} & 1 & 0,01 & 1 \\
\hline & & Total & $100 \%$ & 7161 \\
\hline
\end{tabular}

\section{Phenological characteristics of the material}

The largest numbers of caddisflies were caught in September (2145) (Fig. 2), and the highest number of species (12) was also caught in this month. On average, one species fewer (11) was caught in June, when the number of caddisflies trapped was less than half that in September. There is a similar dependence between the months of July and October. On average, 9 species were trapped in each month, but the overall number of individuals trapped in July was less than half the number caught in October. The large number of species in JuneJuly and September-October is the result of the caddisflies' development and their main flight times. The large numbers of caddisflies caught in September and October comprised mainly $L$. sparsus and L. griseus. Although these species were occasionally caught from May to August, they flew in very large numbers in September and October. Typical autumnal species include Halesus digitatus (Schrank, 1781), H. tesselatus (Rambur, 1842) and Ironoquia dubia (Stephens, 1837). Some species like: S. permistus, L. griseus, L. auricula and L. flavicornis produce a single generation with two distinct peaks in June and again in September. In the Pieniny, Bieszczady and Tatra Mountains the largest numbers of individuals and species were caught in July and August; none of these species are known to have produced two generations in one season (Riedel 1962, 1966, 1978). 


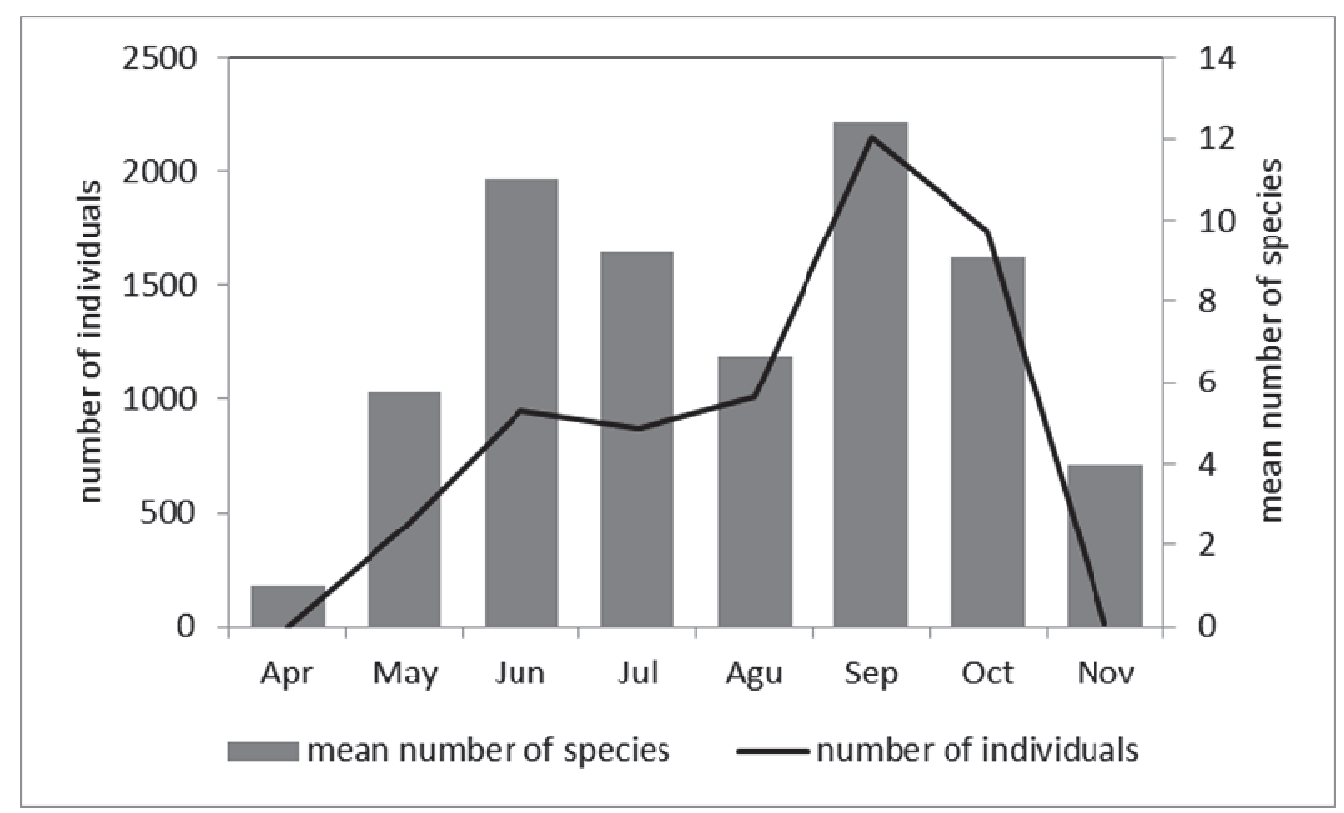

Fig. 2. Mean number of species and number of individuals of caddisflies caught in the Świętokrzyski National Park in different months.

\section{Structural analysis of the Trichoptera community}

The dominance structure was as follows: eudominant - Limnephilus sparsus and L. griseus; dominant - Stenophylax permistus, S. vibex and Limnephilus auricular; subdominant - Halesus digitatus, H. tesselatus, Limnephilus flavicornis, L. ignavus, L. lunatus and L. rhombicus; recedent - the remaining species (Table 1).

Considering the material trapped during this study, the caddisfly fauna of this region is not abundant. Less than five specimens each were caught of more than one third $(34.4 \%)$ of the species. The most frequent and most numerous species were from the family Limnephilidae more than $81 \%$ of all the caddisflies trapped. Limnephilus sparsus Curtis, 1,834 was trapped in the largest numbers $(1,415$ specimens): it was present at all the localities. The largest number of $L$. sparsus individuals was caught at Dąbrowa in 2008 - over $57 \%$ of all the specimens of this species trapped. In later years, however, only small numbers of this species were trapped at this site. L. sparsus was also quite numerous at Gajówka Katy in 2011 (13.8\%) and at Chełmowa Góra in 2008 (7.3\%). Riedel \& Majecki (1989), too, caught quite a large number (82) of this species, both with the sweep net and the light trap. Elsewhere in Poland L. sparsus, a Palaearctic species, is regarded as fairly rare (Czachorowski 1998a). In mountainous areas, it inhabits small pools of water in woodland.

Another species frequently trapped was Limnephilus griseus (Linnaeus, 1758) (801 specimens). It, too, was present at all the localities. The largest numbers of L. griseus were trapped at the Święty Krzyż site in all three years; indeed, more than $67.7 \%$ of $L$. griseus individuals were caught there. Also a Palaearctic species and thought to be a post-glacial relict, it is widespread in Poland. In mountainous areas it is found in small woodland pools and in the source regions of rivers. In the study by Riedel \& Majecki (1989) L. griseus was the most frequent caddisfly species at the light traps (66 specimens). In the Mazurian and Pomeranian 
Lake Districts, L. griseus, like L. sparsus, colonizes astatic water bodies that dry out in summer. In the Karkonosze Mountains, by contrast, these species were caught in mountain tarns, peatbogs, ditches and springs. Mountain habitats are probably close to the ecological optimum of these species (Czachorowski 1991).

The third species - Stenophylax permistus McLachlan, 1895 - was also quite numerous (639 specimens); it occurred at all the trapping sites. The largest number was caught at Dąbrowa in 2008 (241 specimens), but less than half as many (116) were caught at Chelmowa Góra in 2008. An Eurasian, rheophilic species, it was also come across in bodies of standing water.

The diversity (Shannon index) values ranged between 2.03 and 2.94, with relatively high values appearing quite frequently (Fig. 3). This was due to the large number of species and the numerical dominance of one of them. Species like Limnephilus sparsus, L. griseus and Stenophylax permistus attained abundance levels that were much higher than the others at all the collection sites. The Shannon index implementation (J', Pielou index) of $94.4 \%$ indicates that the distribution of particular species was similar to the log-normal distribution (Weiner 2012).

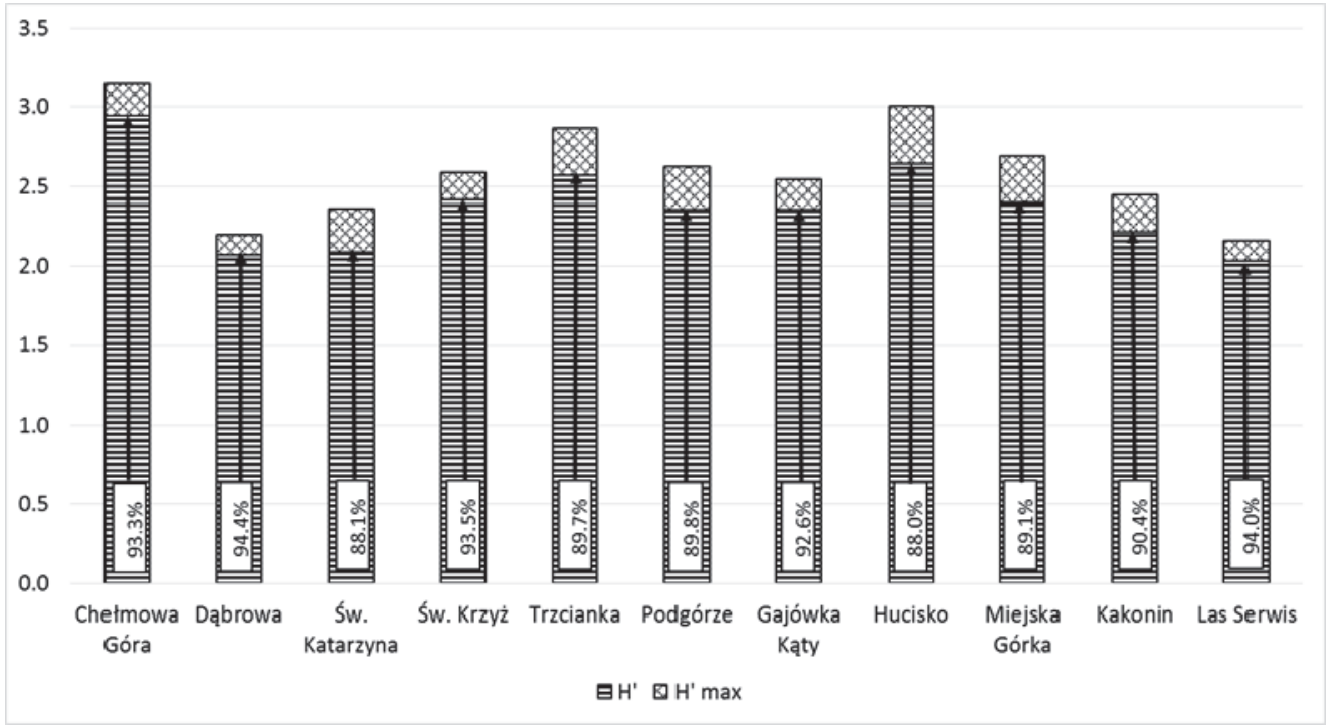

Fig. 3. Values of the Shannon diversity index and the evenness index (expressed in percentage) for caddisflies collected in the study sites of the Świętokrzyski National Park.

\section{General Remarks}

During this seven-year study in the ŚPN we failed to find 16 of the species recorded earlier by Riedel \& Majecki (1989) and Szczęsny (1990) (Table 2). There are a number of reasons why these 16 species were not found. For instance, using a light trap one cannot catch diurnally active caddisflies such as Oligostomis reticullata (Linnaeus, 1767). Some rare species, for example, Crunoecia irrorata (Curtis, 1834), Ptilocolepus granulatus (Pictet, 1834), Lithax obscurus (Hagen, 1859), Adicella filicornis (Pictet, 1834), Beraea pullata (Curtis, 1834), Beraeodes minutus (Linnaeus, 1761), Chaetopterygopsis maclachlani Stein, 1874 and Molannodes tinctus (Zetterstedt, 1840) are placed in most Red Lists and are legally protected. 
The largest number of species was caught at the Chełmowa Góra locality (44), while the poorest in species was the site at Święta Katarzyna (18). Similarity analysis of the species composition indicates that the Bray-Curtis distances were the shortest between the localities at Święty Krzyż and Gajówka Kąty (Fig. 4). There is a similar such distance between these localities and Podgórze. The similarity between the localities at Święty Krzyż (37 species) and Gajówka Kąty (33 species) arises from the 27 species they have in common. Gajówka Kąty and Podgórze (24 species) have 20 species in common, while Święty Krzyż and Podgórze have 19 such species. One species that was caught only at Gajówka Kąty and Święty Krzyż was Holocentropus dubius (Rambur, 1842). Oligotricha striata (Linnaeus, 1758), on the other hand, was also caught at Podgórze. These species are associated with small peatbogs (Czachorowski 1998a), such as those situated mainly in the valley of the spring section of the Czarna Woda, not far away from the Gajówka Katy and Podgórze localities. Moreover, the localities at Trzcianka (26 species) and Kakonin (23 species) - with 18 species common to both - are quite closely connected with respect to species. The Trzcianka and Kakonin localities are on the southern slope of the Łysogóra Range, where there are few surface waters. The similarity of the various localities was characterized above all by their close proximity and the number of species.

Table 2. Trichoptera species, whose occurrence in the Świętokrzyski National Park was not confirmed in the current studies.

\begin{tabular}{|c|c|c|c|}
\hline \multirow{2}{*}{ No. } & \multirow{2}{*}{ Species } & \multicolumn{2}{|c|}{ Described by: } \\
\hline & & Riedel \& Majecki 1989 & Szczęsny 1990 \\
\hline & Rhyacophila obliterata McLachlan, 1865 & & + \\
\hline 2. & Rhyacophila tristis Pictet, 1834 & + & + \\
\hline 3. & Ptilocolepus granulatus (Pictet, 1834) & & + \\
\hline 4. & Wormaldia occipitalis (Pictet, 1834) & + & + \\
\hline 5. & Lype reducta (Hagen, 1868) & + & \\
\hline 6. & Oligostromis reticullata (Linnaeus, 1767) & + & \\
\hline 7. & Limnephilus centralis Curtis, 1834 & + & \\
\hline 8. & Chaetopterygopsis maclachlani Stein, 1874 & & + \\
\hline 9. & Lithax obscurus (Hagen, 1859) & + & + \\
\hline 10 . & Crunoecia irrorata (Curtis, 1834) & & + \\
\hline & Athripsodes sp. (commutauts?) & & + \\
\hline & Adicella filicornis (Pictet, 1834) & & + \\
\hline 13. & Notidobia ciliaris (Linnaeus, 1761) & + & \\
\hline 14. & Beraea pullata (Curtis, 1834) & + & \\
\hline 15. & Beraeodes minutus (Linnaeus, 1761) & & + \\
\hline 16. & Molannodes tinctus (Zetterstedt, 1840) & + & + \\
\hline
\end{tabular}

The caddisfly fauna of both the ŚPN and the ŚM as a whole does not have any species unique to this region: most of the species are also found in lowland and upland regions all over Poland. This statement is confirmed by the faunistic similarity indices calculated using Jaccard's formula. The faunistic similarity index between the ŚM and lowland regions of Poland was relatively high, above 50\% (Pomeranian Lake District - 51, Wielkopolska-Kujawy Lowland - 63, Masurian Lake District -61$)$. The faunistic similarity between the ŚM and upland regions of the country ranged from 54\% (Małopolska Upland) to 21\% (Lublin Upland). The similarity index was the lowest for mountain regions (Sudetens $-30 \%$, Tatras $-34 \%$, Pieniny Mts. $-28 \%$, Bieszczady Mts. $-27 \%$ ). The checklist of caddisflies in the ŚPN should not be treated as closed. The record of a species new to Poland (Stenophylax vibex), hitherto occurring exclusively in the ŚPN, as well as the record of 53 species new to the ŚPN and 19 
new to the SM, are indications that the state of knowledge of this very specific environment is still far from satisfactory.

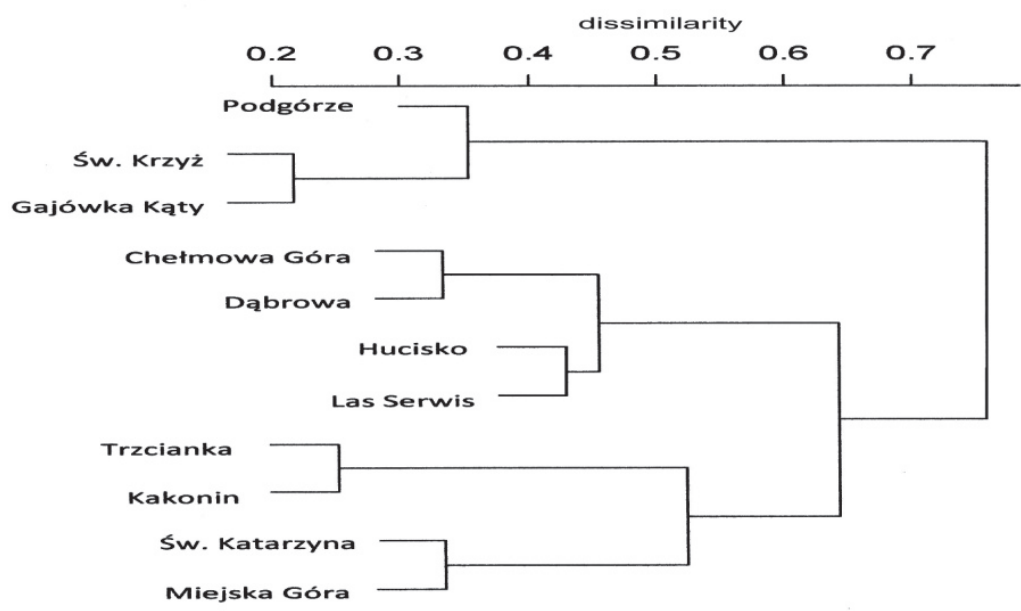

Fig. 4. Dendrogram showing the dissimilarity of caddisfly fauna from the study sites in the Świętokrzyski National Park (based on Bray-Curtis index and obtained by Ward's linkage method).

\section{REFERENCES}

Abraszewska-Kowalczyk A., Kowalczyk J., Hejduk J., PrZybylski M. \& Tuszewski W. 2002. Świat zwierząt Brudzeńskiego Parku Krajobrazowego. Mantis, Olsztyn, 101 pp.

Banaszak J., Buszko J., Czachorowski S., Czechowska W., Hebda G., Liana A., PawŁowski J., SzePtycki A., TROJAN P. \& WĘGIEREK P. 2004. Przegląd badań inwentaryzacyjnych nad owadami w parkach narodowych Polski. [A review of inventory research on insects in the national parks of Poland]. Wiadomości Entomologiczne 23, Suplement, Poznań, 2: 5-56. [In Polish with English Abstract]

BieRnAT T., CiUPA T., KuPCZYK E. \& SuligOwSKi R. 2009. Zagrożenia środowiska wodnego Świętokrzyskiego Parku Narodowego i jego otuliny. In: ANDRZEJEWSKA A., LUBAŃSKI A. (ed.), Trwałość i efektywność ochrony przyrody w polskich parkach narodowych. KPN. Izabelin.

BIESIADKA E. \& KoWALIK W. 1980. Water mites (Hydracarina) of Western Bieszczady Mountains. I. Stagnant waters. Acta hydrobiologica, Warszawa, Kraków, 22: 279-298.

Bis B., OleJNIK V., MAJECKI J., Higler L. \& VerdonsChOT P. 1992. Distribution pattern and structure of Trichoptera assemblages in the Lubrzanka river (Świętokrzyskie Mountains central Poland), pp. 213-217. In: OTTO C. (ed.) Proceedings of the $7^{\text {th }}$ International Symposium of Trichoptera. Umeå, Sweden, 3-8 August 1992. Bakhuys Pub. Leiden, the Netherlands, $312 \mathrm{pp}$.

BuCZYŃSKA E. 2006. Chruściki (Trichoptera) Roztoczańskiego Parku Narodowego - stan poznania i perspektywy. [Caddisflies (Trichoptera) of the Roztoczański National Park - the state of recognition and perspectives]. Wiadomości Entomologiczne 25, Suplement, Poznań, 2: 39-50. [In Polish with English Abstract]

BUCZYŃSKA E. 2008. The caddisflies (Trichoptera) of spring in the Roztocze region (south-eastern Poland). Annales Universitatis Mariae Curie-Skłodowska, Lublin, 63/2: 13-22.

BUCZYŃSKA E., BUCZYŃSKi P. \& LECHOWSKI L. 2007 Wybrane owady wodne (Odonata, Heteroptera, Coleoptera, Trichoptera) Narwiańskiego Parku Narodowego - wyniki wstępnych badań. [Selected aquatic insects (Odonata, Heteroptera, Coleoptera, Trichoptera) of Narwiański National Park - results of preliminary studies]. Parki Narodowe i Rezerwaty Przyrody, Białowieża, 26/1: 25-40. [In Polish with English Abstract]

CiUPA T., Biernat T. \& Suligowski R. 2012. Świętokrzyski park narodowy. In. BogdanOwiCz K., JOKIEL P., PoCIASK-KARTECZKA J. (ed.), Wody w parkach narodowych Polski, pp. 296-309. Instytut Geografii i Gospodarki Przestrzennej, Komisja Hydrologiczna Polskiego Towarzystwa Geograficznego, Kraków. 392 pp.

CIUPA T. \& SOŁTYSIK R. 2002. Geomorfologiczne i hydrograficzne skutki współczesnej mobilności tektonicznej w dolinie rzeki Czarna Woda. In: TRACZYK A., LATOCHA A, (ed.), Środowisko górskie - ewolucja rzeźby. Materiały Zjazdu Geomorfologów Polskich, pp. 32-33 Stowarzyszenie Geomorfologów Polski. Uniwersytet Wrocławski, Wrocław, $152 \mathrm{pp}$. 
CZACHOROWSKI S. 1991. Chruściki (Trichoptera) Karkonoszy: przyczynek do znajomości rozmieszczenia larw. [Some notes on the distribution of caddish-flies larvae of the Karkonosze Mountains]. Fragmenta Faunistica 35: 151-166. [In Polish with English Abstract and Summary]

CZACHOROWSKI S. 1994. Stan badań nad poznaniem fauny chruścików (Insecta, Trichoptera) Polski PółnocnoWschodniej. [State of knowledge od caddisflies (Trichoptera) of North-Eastern Poland]. Przegląd zoologiczny, Białowieża, 38: 221-231. [In Polish with English Summary]

CzACHOROWSKI S. 1998a. Chruściki (Trichoptera) jezior Polski - charakterystyka rozmieszczenia larw. Wydawnictwo Wyższej Szkoły Pedagogicznej, Olsztyn;156 pp.

Czachorowski S. 1998b. Chruściki (Trichoptera) Puszczy Białowieskiej - stan poznania. [Caddis flies (Trichoptera) of the Białowieża Forest - the state of knowledge]. Parki Narodowe i Rezerwaty Przyrody, Białowieża 17 (3) (Supl.): 49-54. [In Polish with English Abstract]

CZAChorowski S., BuCZyŃSKi P. \& STRYJECKI R. 2000. Chruściki (Trichoptera) Parku Krajobrazowego Lasy Janowskie. [Caddisflies (Trichoptera) Janowskie Forests Landscape Park]. Parki Narodowe i Rezerwaty Przyrody, Białowieża, 19: 65-84. [In Polish with English Abstract]

CZACHOROWSKI S. \& FRĄCKIEL K. 2003. Nowe i prawdopodobnie jedyne stanowisko Semblis phalaenoides (Linnaeus, 1758) (Trichoptera: Phryganeidae) w Polsce. [New and probably the only locality of Semblis phalaenoides (Linnaeus, 1758) (Trichoptera: Phryganeidae) in Poland]. Wiadomości Entomologiczne, Poznań, 22 (3): 169-172. [In Polish with English Abstract]

CZACHOROWSKI S. \& GRAF W. 2006. Nowe dane o chruścikach Doliny Biebrzy (i Narwi). Trichopteron 19: 10-11.

CZACHOROWSKi S. \& MAJEWSKI T. 2003. Stan poznania chruścików (Trichoptera) obszarów chronionych Polski. [State of knowledge of caddisflies (Trichoptera) Polish protected areas]. Rocznik Naukowy Polskiego Towarzystwa Ochrony Przyrody „Salamandra”, Poznań, 7: 167-181. [In Polish with English Summary]

CZAChorowski S., SERAFIn E. \& BUCZYŃSKi P. 2002. Chruściki (Insecta: Trichoptera) województwa lubelskiego stan poznania. [Caddis-flies (Insecta: Trichoptera) Lublin province - the state of knowledge]. Przegląd Przyrodniczy, Świebodzin, 13: 91-102. [in Polish with English Abstract ]

DEGÓRSKI M. 2007. Wpływ emisji zanieczyszczeń do atmosfery na stan i funkcjonowanie pedosfery w wybranych geoekosystemach Polskich. In: OSTASZEWSKa K., SZumacher I., KulcZYK S., MalinOwSKA E. (ed.), Znaczenie badań krajobrazowych dla zrównoważonego rozwoju, pp. 269-282. Wydawnictwa Uniwersytetu Warszawskiego, Warszawa, $722 \mathrm{pp}$.

GÓRECKI K \& BUSZKO J. 2014 Nowe stanowisko Semblis phalenoides (LINNAEUS, 1758) (Trichoptera: Phryganeidae) w północno-wschodniej Polsce [New locality of Semblis phalenoides (LINNAEUS, 1758) (Trichoptera: Phryganeidae) in Northeastern Poland]. Wiadomości Entomologiczne, Poznań, 33 (3): 219. [In Polish]

GóRECKI K. \& CzACHOROWSKI S. 2010. Stenophylax vibex (Curtis, 1834) (Trichoptera: Limnephilidae), a new species for the Polish fauna. Polish Journal of Entomology 79: 101-105.

Hohmann M., Gohr F., Jahrling M., Klieinsteuber W. \& Tappenbeck L. 2004. Rote Liste der Köcherfliegen (Trichoptera) des Lands Sachsen - Anhalt. Rote Listen Sachsen - Anhalt. Berichte des Landesamtes für Umweltschutz Sachsen - Anhalt 39: 205-211.

Klima F. 1998. Rote Liste der Köcherfliegen (Trichoptera). In: BinOt M. Bless, R., Boye P., GruttKe H., PRETSCHER P. Rote Liste gefährdeter Tiere Deutschlands. Schriftenreihe für Landschaftspflege und Naturschutz, 55: $112-118$.

KuPCZYK E., Biernat T., CiUPA T. \& SuligOwSKi R. 2000. Wody powierzchniowe i podziemne Gór Świętokrzyskich. In:. CIEŚLIŃSKI S., KowALKOWSKI A. (ed.), Monografia Świętokrzyskiego Parku Narodowego, pp. 147-167. ŚPN, Bodzentyn - Kraków, 629 pp.

MagurRan, A. E. 2004. Measuring biological diversity. Oxford: Blackwell Publishing, 215 pp.

MAJECKI J. 1982. Chruściki (Trichoptera) rzeki Lubrzanki w Górach Świętokrzyskich. [The caddis flies (Trichoptera) of the Lubrzanka River in the Świętokrzyskie Mountain]. Acta Universtatis Lodziensis. Folia Limnologica, Łódź, 1: 51-60. [In Polish with English Abstract and Summary]

PONGRÁCZ A. 1919. Beiträge zur Pseudoneuropteren und Neuropterenfauna Polens. [Contributions to the Pseudoneuroptera and Neuroptera in the Polish fauna]. Annales Historico-Naturales Musei Nationalis Hungarici, Budapest, 17: 161-177.

PRÜFFER J. 1922. Neuronia phalaenoides L. nowy gatunek chróścika dla fauny Ziem Polskich. Annales Zoologici Musei Polonici. Historiae Naturalis, Warszawa, 1 (2-3): 147-148.

R CORE TEAm 2013. R: A language and Environment for Statistical Computing. R Foundation for Statistical Computing, Vienna, Austria. Available at http://www.r-project.org

RIEDEL W. 1962. Chruściki (Trichoptera) Tatr. Fragmenta Faunistica 9: 417-438.

RiEdEL W. 1978. Chruściki (Trichoptera) Pienin. Fragmenta Faunistica, Warszawa, 22: 247-263.

RIEDEL W. \& MAJECKI J. 1989. Postacie doskonałe chruścików (Trichoptera) Gór Świętokrzyskich. [Adult forms of caddisflies (Trichoptera) of the Świętokrzyskie Mountains]. Fragmenta Faunistica, Warszawa, 32: 227-241. [In Polish] 
Riedel W. \& MAJECKI J. 1994. Chruściki (Trichoptera) Roztocza. [Caddisflies (Trichoptera) of the Roztocze]. Fragmenta Faunistica, Warszawa, 37: 315-322. [In Polish with English Abstract and Summary]

RYCHŁA A. \& BUCZYŃSKA E. 2013. Species richness and diversity of caddisflies (Trichoptera) in a selected area in mid-western Poland (Lubuskie Province). Annales Universitatis Mariae Curie-Skłodowska, Lublin, 68/1: 55-73.

SERAFIN E. 2004. Nowe stanowiska Hydatophylax infumatus (Mac Lachlan, 1865) (Trichoptera: Limnephilidae) w południowo-wschodniej Polsce. [New localities of Hydatophylax infumatus (McLachlan, 1865) (Trichoptera: Limnephilidae) in South-Eastern Poland]. Wiadomości Entomologiczne, Poznań, 23/4: 247-248. [In Polish with English Abstract]

SzCZEPAŃSKA W. 1958. Chruściki Pojezierza Mazurskiego. Polskie Archiwum Hydrobiologii, Warszawa, 5 (18): $143-160$.

SZCZESNY B. 1965. Caddisflies (Trichoptera) of the Dunajec. In: DRATNAL E., SZCZESNY B. (ed.), Benthic fauna of the Dunajec River. Komitet Zagospodarowania Ziem Górskich PAN, Kraków, 11: 190-195.

SZCZESNY B. 1986. Caddisflies (Trichoptera) of running waters in the Polish North Carpathians. Acta Zoologica Cracoviensia, Kraków, 29: 501-586.

SZCZĘSNY B. 1990. Benthic macroinvertebrates in acidified streams of the Świętokrzyski National Park (central Poland). Acta Hydrobiologica, Kraków, 32: 155-169.

SZCZĘSNY B. 2002. Trichoptera Chruściki. [Trichoptera Caddisflies]. In: GŁowACiŃSKI Z. (ed.): Czerwona lista zwierząt ginących i zagrożonych w Polsce. Wydawnictwo Instytutu Ochrony Przyrody PAN, Kraków: 76-79.

TOMASZEWSKI C. 1965. Chruściki - Trichoptera. [Caddisflies - Trichoptera]. Katalog Fauny Polski. 28. Państwowe Wydawnictwo Naukowe, Warszawa, 104 pp.

WeINER J. 2012. Życie i ewolucja biosfery. Podręcznik ekologii ogólnej. Państwowe Wydawnictwo Naukowe, Warszawa: $590 \mathrm{pp}$.

ŻURAWleW P., CZACHOROWSKi S. \& BUCZYŃSKi P. 2015. Chruściki (Trichoptera) okolic Pleszewa (Wielkopolska). [Caddisflies (Trichoptera) in the area of Pleszew (Wielkopolska)]. Przegląd Przyrodniczy, Świebodzin, 26 (1): 39 44. [In Polish with English Abstract]

\section{STRESZCZENIE}

\section{[Chruściki (Trichoptera) Świętokrzyskiego Parku Narodowego]}

W badaniach prowadzonych w latach 2008-2014 na terenie Świętokrzyskiego Parku Narodowego (ŚPN) stwierdzono występowanie 82 gatunków chruścików (Trichoptera). Teren ŚPN wchodzi w skład obszaru Natura 2000 - Łysogóry (PLH260002). Owady łowione były metodą na światło w 10 punktach na terenie ŚPN oraz w jednym punkcie przy granicy parku, w otulinie. Stwierdzono występowanie między innymi pięciu gatunków z Czerwonej Listy: Hydatophylax infumatus (McLachlan, 1865), Rhadicoleptus alpestris (Kolenati, 1848), Ceraclea alboguttata (Hagen, 1860), Oecetis notata (Rambur, 1842), Ylodes simulans (Tieder, 1929) oraz jeden gatunek nowy dla fauny Polski - Stenophylax vibex (Curtis, 1834), który wykazano, jak dotąd, tylko na terenie ŚPN. Podczas prowadzonych badań znaleziono 53 gatunki chruścików nie wykazanych wcześniej w ŚPN i 19 gatunków nowych dla Gór Świętokrzyskich. Największą liczbę gatunków i osobników odławiano w miesiącach czerwiec i wrzesień. Gatunki Limnephilus sparsus Curtis, 1834, L. griseus (Linnaeus, 1758) i Stenophylax permistus McLachlan, 1895 dominowały niemal we wszystkich punktach odłowu owadów. Nie udało się potwierdzić występowania 16 gatunków, w większości gatunków z Czerwonej Listy oraz rzadkich. Faunę chruścików ŚPN w większości tworzą gatunki spotykane w innych regionach Polskich. Wysoki indeks podobieństwa faunistycznego stwierdzono pomiędzy Górami Świętokrzyskimi a terenami nizinnymi Polski. Wyniki powyższych badań powiększają liczbę gatunków chruścików występujących na terenie ŚPN do 98. 